\title{
Risk Factors Predicting Hypovitaminosis D in Children in South-East Region of Bangladesh
}

\author{
Pranab Kumar Chowdhury1, Pradip Kumar Dutta ${ }^{2 *}$, Arup Kumar Dutta ${ }^{3}$, Aditi Chowdhury ${ }^{4}$, \\ Janardan Mahanta5, Pujanjoli Chowdhury6
}

\author{
${ }^{1}$ Department of Paediatrics, Chittagong Medical College, Chattogram, Bangladesh \\ ${ }^{2}$ Department of Research Division, Marine City Medical College, Chattogram, Bangladesh \\ ${ }^{3}$ Department of Paediatrics, BGC Trust Medical College, Chattogram, Bangladesh \\ ${ }^{4}$ Sheik Russel National Gastroliver Institute and Hospital, Dhaka, Bangladesh \\ ${ }^{5}$ Department of Statistics, University of Chittagong, Chattogram, Bangladesh \\ ${ }^{6}$ Dhaka Medical College Hospital, Dhaka, Bangladesh \\ Email: *duttaprd@gmail.com
}

How to cite this paper: Chowdhury, P.K., Dutta, P.K., Dutta, A.K., Chowdhury, A., Mahanta, J. and Chowdhury, P. (2022) Risk Factors Predicting Hypovitaminosis D in Children in South-East Region of Bangladesh. Journal of Biosciences and Medicines, 10, 44-55.

https://doi.org/10.4236/jbm.2022.103006

Received: January 15, 2022

Accepted: March 1, 2022

Published: March 4, 2022

Copyright $\odot 2022$ by author(s) and Scientific Research Publishing Inc. This work is licensed under the Creative Commons Attribution International License (CC BY 4.0).

http://creativecommons.org/licenses/by/4.0/

\section{(c) (i) Open Access}

\begin{abstract}
Background: Hypovitaminosis D (serum concentration of 25(OH)D $<20$ $\mathrm{ng} / \mathrm{ml}$ ) has been observed in temperate to tropical zones throughout world. Aim of this study is to determine the prevalence of Hypovitaminosis D among children in South-East region of Bangladesh and also explore its association with socio-demographic profile, weight, feeding pattern, residence, seasonal variation, degree of sun exposure, education type and schooling pattern. Methods: This was a cross sectional observational study having conducted at a paediatric clinic in Chittagong Metropolitan City from July, 2012 to December, 2017 including 524 children of 0 - 18 years by convenient sampling. The relevant data were assessed using standard case record form and lab parameter of $25(\mathrm{OH}) \mathrm{D}$ assay. Serum level of $25(\mathrm{OH}) \mathrm{D}$ of $<20 \mathrm{ng} / \mathrm{ml}$ was taken as Hypovitaminosis D. Anaemia was defined as $\mathrm{Hb}$ level less than 11 gm\%. Results: The prevalence of Hypovitaminosis D was 50.57\%. Compared with the infancy age group the odds of Hypovitaminosis D is 1.36 times more likely in $>5$ yrs children. The odds of association (odds ratio or $\mathrm{OR}=0.19$ ) of rural population with Hypovitaminosis D is lower than urban population. The formula fed children had less chance of association $(\mathrm{OR}=0.32)$ of developing hypovitaminosis $\mathrm{D}$ in comparison to exclusively breastfed babies. Occasional Sun exposed group was 1.40 times more likely to develop hypovitaminosis $\mathrm{D}$ in comparison to daily sun exposure group. The odds of Hypovitaminosis $\mathrm{D}$ were 1.9 times more in winter season than summer season. School going children had double the chance of Hypovitaminosis D than children with no education. Subjects with high weight for age were 3.65 times increased risk of suffering from hypovitaminosis D compared with normal
\end{abstract}


weight for age. Girls had a little bit more chance of hypovitaminosis D than boys. Children coming from family with monthly Income $>10,000$ BDT are associated with more Hypovitaminosis D. Among clinical variables only wheeze has significant association $(\mathrm{OR}=1.83)$. Conclusion: Hypovitaminosis D $(<20 \mathrm{ng} / \mathrm{ml})$ prevails significantly among Infants and children of South-East region of Bangladesh. Age, area of residence, feeding pattern, sun exposure practice, seasons, schooling pattern, weight for age have strong association with Hypovitaminosis D.

\section{Keywords}

Hypovitaminosis D, Children, Bangladesh

\section{Introduction}

Vitamin D plays a pivotal role in health and disease [1]. Hypovitaminosis D is implicated as a risk factor for many diseases right from conception throughout life span [2]. Deficiency of Vitamin D leads to hypocalcaemia and hypophosphataemia with resultant rickets in children and Osteomalacia in adults, but these are rarely seen in areas of abundant sunshine and history of taking Vit D rich Foods. Lack of Vitamin D has its effect on body's Endocrine system, Immune system, Cardio Vascular System and Neuropsychological functioning. Vit $\mathrm{D}$ has a potent antioxidant protecting effect against carcinogenesis. Hence hypovitaminosis $\mathrm{D}$ is a risk factor for many diseases [2].

Vitamin D deficiency has been reported in Europe, America, Middle East, Africa, and Asia. Even it is more frequent in the sunny Mediterranean, south Asian, and their neighboring countries like China, Japan, and Thailand [3]. Most commonly Hypovitaminosis D in paediatric population is often asymptomatic. In Northern China about $42 \%$ of infants with Hypovitaminosis D suffer from Rickets [4]. Vitamin D is mainly derived from sunlight by ultraviolet radiation and only $10 \%$ from diet [5]. Vitamin D deficiency is not only prevalent in western country, it is surprising to note that hypovitaminosis $\mathrm{D}$ is highly prevalent even in areas with adequate sunshine. [2] [6]. It may be due to skin pigmentation and traditional clothing [7]. Modern day lifestyle changes have significantly reduced the total duration of sun exposure in children. Ultraviolet $\mathrm{B}$, having shorter wavelength, tends to scatter earlier or later in the day. Hence cutaneous vitamin D synthesis is maximum from $10 \mathrm{AM}$ to $3 \mathrm{PM}$, the time when most of the children are either in school or indoors. Exposure of only face, hands and arms due to clothing versus whole body is associated with marked differences in vitamin D synthesis [8]. Dietary factors like very low calcium intake and high fiber diet may deplete vitamin D stores [9]. Genetic factors like increased 25(OH)D, 24-hydroxylase (leading to degradation of vitamin D) activity in South Asians are also among the various explanations in sunny countries [10].

As vitamin D crosses the placenta and poor vitamin D content of breast milk, 
maternal vitamin deficiency and exclusive breastfeeding without vitamin D supplement or adequate sunlight exposure are important risk factors for vitamin $\mathrm{D}$ deficiency in infants. Fortifying foods with vitamin D remains the only alternative when cutaneous synthesis is inadequate. An Asian would require three times the sun exposure than light skinned person to produce equivalent amount of vitamin D [11]. In the absence of adequate sun exposure, 800 - 1000 IU vitamin D3/day may be needed to achieve this in children [12].

Though there are many studies regarding Hypovitaminosis D in adult population, data is scarce in paediatric population. In India the prevalence in children is $62 \%$ [13]. In Northern Pakistan instead of abundant Sun light ricket is prevalent due to malnutrition, lack of awareness and antenatal care [14]. In Japan Hypovitaminosis D is rare due to high sea fish consumption [15]. Vitamin D insufficiency of Children of Australia, Turkey and Lebanon varies between 30\% $50 \%$ [16] [17]. The cut off point for Hypovitaminosis D is still controversial. In most of the studies, serum level of $25(\mathrm{OH})$ of $20 \mathrm{ng} / \mathrm{ml}$ is taken as Hypovitaminosis D [18]. Though there are many studies in Bangladesh regarding Hypovitaminosis $\mathrm{D}$ in adult population, data is scarce in pediatric population [19] [20] [21]. This study was therefore conducted to find out prevalence and factors associated with Hypovitaminosis D in children in South-East Region of Bangladesh.

\section{Methods}

This cross sectional study was conducted in a private pediatric outpatient clinic in metropolitan area of Chattogram in south eastern region of Bangladesh over a period of sixty six months from July 2012 to December 2017. Considering the anticipated prevalence of Hypovitaminosis D of 50\%, to fall within 5\% of true prevalence with $95 \%$ confidence, the required sample size was 384 [6]. We included 524 children of $0-18 \mathrm{yrs} .25(\mathrm{OH}) \mathrm{D}$ level $<20 \mathrm{ng} / \mathrm{ml}$ was considered as Hypovitaminosis D. The study protocol was approved by the ethical committee of Department of Statistics, Faculty of Science of Chittagong University. Caregivers were provided with an informed consent or assent in written form. Children with severe malabsorption, taking anticonvulsants, suffering from Nephrotic syndrome, severe Hepatocellular disease and Renal disease were excluded. A case record form exploring socio-demographic profile, feeding habit, life style, schooling and environmental variation was developed. Body weight was measured to the nearest $100 \mathrm{gm}$ up to upto $12 \mathrm{~kg}$ infant in MISAKI infant weighing scale. In older child with the subjects wearing no shoes, having light clothing and standing on a portable in RGZ-160 weighing machine to the nearest $0.5 \mathrm{~kg}$ then plotting in NCHS percentiles Growth Charts. For measurement of 25-OH Vitamin D, $5 \mathrm{ml}$ venous blood sample was taken for each case by disposable syringe, and was collected in a red capped tube (no anticoagulant) which was sent to centrifuge machine (Rotofix 32 A, 3000 RPM) after $1 \mathrm{hr}$. of collection in a standard lab in the Metropolitan city under supervision of Medical Bioche- 
mistry consultant. With 10 minutes centrifugation the separated serum of sample cup (300 micro liter) was put in the Auto machine (Cobas: Elecsys 2010) for measuring 25(OH)D by Eletro-Chemiluminescence's in ADVIA centaur XP/Elecsys 2010/Immulite $2000 \mathrm{xPi}$ and, the result was provided 24 minutes later. Data were analyzed by $\mathrm{Z}$ score calculator for proportion and MedCalc statistical software for Windows. One tailed $\mathrm{P}$ value of less than 0.05 was considered statistically significant.

\section{Results}

A total of 524 children were included in the study. Among the study subjects, hypovitaminosis $\mathrm{D}(<20 \mathrm{ngm} / \mathrm{ml})$ was noticed in more than half of the case (265, 50.57\%). It was observed that Hypovitaminosis D was significantly lower among children in 1 - 5 years compared to the infancy. There was no statistically significant difference between the infant group and $>5$ years groups (Table 1), however there is higher odds of association (1.36) with hypovitaminosis D in age group $>5$ years compared to infancy though it is clinically and statistically not significant $(\mathrm{p}=0.2675)($ Table 2$)$.

In the study population boys of hypovitaminosis $\mathrm{D}$ were noticed in 166 cases out of 337 (49.25\%) whereas 99 out of 187 girls (52.94\%) suffered from hypovitaminosis D. There was no significant difference between gender (Table 1), although girls had a little significant Association (1.15) (Table 2).

Among 265 patients with hypovitaminosis D, a significantly higher proportion of children resides in urban area than rural area (79.90\% vs $43.55 \%)$ (Table 1). Rural children had also lower odds of association with Hypovitaminosis $D$ (OR 0.19) which is both clinically (CI: $0.1264-0.2980$ ) and statistically ( $\mathrm{p}=$ 0.0001) significant (Table 2).

There was a statistically significant difference of Hypovitaminosis D and feeding patterns. Formula feeding is significantly less associated with Hypovitaminosis D $(\mathrm{p}=0.005)$ (Table 1). Table 2 revealed that the level of vitamin $\mathrm{D}$ was statistically significantly lower among exclusive breast feed children compared to the formula feeding ( $\mathrm{p}=0.013$, OR $=0.32$ ). There was no statistically significant difference between exclusive breast feeding children and the home made feeding children $(\mathrm{p}=0.05)$ (Table 1$)$.

Though statistically significant proportion $(p=0.03)$ of children coming from higher income family suffered from Hypovitaminosis D (Table 1) but in multivariate analysis it is not clinically significant $(\mathrm{CI}=0.9594-2.8318)$.

Children with low weight for age had less association with Hypovitaminosis D $(\mathrm{OR}=0.74)$ compared with children with normal weight for age (Table 2). But in children with high weight for age had significant association $(\mathrm{OR}=3.65)$ but this association is imprecise $(\mathrm{CI}=1.19$ - 11.16).

Children going to Kindergarten, Primary and higher schools had significant proportion of Hypovitaminosis D compared with children not going to school (Table 1). Children going to primary school had both statistically and clinically significant association $(\mathrm{OR}=2.19, \mathrm{p}=0.005, \mathrm{CI}=1.41-3.41)$ (Table 2). 
Table 1. Prevalence of Hypovitaminosis D of participants with respect to socio-demographic, feeding pattern, schooling and seasonal factors $(\mathrm{N}=524)$.

\begin{tabular}{|c|c|c|c|}
\hline Parameter & $\begin{array}{l}\text { Frequency } \\
(\mathrm{N}=524)\end{array}$ & $\begin{array}{l}\text { Hypovitaminosis D } \\
(\mathrm{n}=265)^{\dagger}\end{array}$ & $P$-value ${ }^{t}$ \\
\hline \multicolumn{4}{|l|}{ Age (years) } \\
\hline Infancy & 72 & $39(54.16 \%)$ & \\
\hline $1-5$ & 269 & $113(42 \%)$ & 0.03288 \\
\hline$>5$ & 183 & $113(61.75 \%)$ & 0.1335 \\
\hline \multicolumn{4}{|l|}{ Gender } \\
\hline Boy & 337 & $166(49.25 \%)$ & 0.208 \\
\hline Girls & 187 & $99(52.94 \%)$ & \\
\hline \multicolumn{4}{|l|}{ Weight for age } \\
\hline Normal & 306 & $160(52.29)$ & \multirow{3}{*}{$\begin{array}{c}0.05 \\
0.007\end{array}$} \\
\hline Low & 198 & $89(44.95 \%)$ & \\
\hline High & 20 & $16(80 \%)$ & \\
\hline \multicolumn{4}{|l|}{ Residence } \\
\hline Urban & 209 & $167(79.90 \%)$ & \multirow[t]{2}{*}{0.00001} \\
\hline Rural & 225 & $98(43.55 \%)$ & \\
\hline \multicolumn{4}{|l|}{ Monthly Income (BDT) } \\
\hline$\leq 10,000$ & 73 & $31(42.46 \%)$ & 0.149 \\
\hline$>10,000-20,000$ & 177 & $88(49.71 \%)$ & 0.03 \\
\hline$>20,000-50,000$ & 191 & $105(54.97 \%)$ & 0.192 \\
\hline$>50,000$ & 83 & $41(49.39 \%)$ & \\
\hline \multicolumn{4}{|l|}{ Feeding Pattern } \\
\hline Exclusive breast feeding & 30 & $20(66.67 \%)$ & \multirow{3}{*}{$\begin{array}{c}0.005 \\
0.05\end{array}$} \\
\hline Formula feeding & 69 & $27(39.13 \%)$ & \\
\hline Homemade feeding & 425 & $218(51.29 \%)$ & \\
\hline \multicolumn{4}{|l|}{ Schooling } \\
\hline No education & 317 & $142(44.79 \%)$ & \multirow{4}{*}{$\begin{array}{c}03 \\
0.0002 \\
0.0002\end{array}$} \\
\hline Kindergarten & 77 & 40 (51.95\%) & \\
\hline Primary & 114 & $73(64.04 \%)$ & \\
\hline High & 16 & $10(62.5 \%)$ & \\
\hline \multicolumn{4}{|l|}{ Sun exposure } \\
\hline Daily & 223 & $102(45.74 \%)$ & \multirow{2}{*}{0.02872} \\
\hline Occasionally & 301 & $163(54.15 \%)$ & \\
\hline \multicolumn{4}{|l|}{ Seasonal variation } \\
\hline Summer & 155 & $74(28.39 \%)$ & \multirow{4}{*}{$\begin{array}{c}0.21 \\
0.44 \\
0.003\end{array}$} \\
\hline Rainy & 79 & $31(39.24 \%)$ & \\
\hline Spring & 145 & $68(46.9 \%)$ & \\
\hline Winter & 145 & $92(63.45 \%)$ & \\
\hline
\end{tabular}

${ }^{\dagger}$ Figures within parentheses denote \% of children of Hypovitaminosis D in the same category. ${ }^{\text {t }}$ different categories were compared with $1^{\text {st }}$ category in each parameter.

Children with daily sun exposure less suffered from Hypovitaminosis D than those with occasional sun exposure $(\mathrm{p}=0.02)$ and occasional sun exposure is more associated with Hypovitaminosis D $(\mathrm{OR}=1.4)$ (Table 2). 
Table 2. Multivariate logistic regression analysis of association between Hypovitaminosis $\mathrm{D}$ and various socio-demographic and other variables.

\begin{tabular}{|c|c|c|c|c|}
\hline Variable & Category & $P$ value & $\begin{array}{c}\text { Confidence } \\
\text { interval }\end{array}$ & Odds ratio \\
\hline \multirow{3}{*}{ Age } & Infancy (Ref) & & & \\
\hline & $1-5$ years & 0.0666 & $0.3633-1.0341$ & 0.6129 \\
\hline & $>5$ years & 0.2675 & $07872-2.3703$ & 1.3659 \\
\hline \multirow{2}{*}{ Residence } & Urban (Ref) & & & \\
\hline & Rural & $<0.0001$ & $0.1264-0.2980$ & 0.1941 \\
\hline \multirow{3}{*}{ Feeding History } & clusive breastfeeding ( $\mathrm{Re}$ & & & \\
\hline & Formula feeding & 0.0134 & $0.1307-0.7906$ & 0.3214 \\
\hline & Home Made feeding & 0.1082 & $0.2408-1.1517$ & 0.5266 \\
\hline \multirow{2}{*}{ Gender } & Male (Ref) & & & \\
\hline & Female & 0.4193 & $0.8103-1.6575$ & 1.1589 \\
\hline \multirow{3}{*}{ Weight for age } & Normal (Ref) & & & \\
\hline & Low & 0.1079 & $0.5204-1.0666$ & 0.7451 \\
\hline & High & 0.02 & $1.1928-11.1689$ & 3.65 \\
\hline \multirow{4}{*}{ Schooling type } & No education (Ref) & & & \\
\hline & Kindergarten & 0.2596 & $0.8090-2.1941$ & 1.3323 \\
\hline & Primary & 0.0005 & $1.4104-3.4137$ & 2.1943 \\
\hline & Higher & 0.1733 & $0.7289-5.7884$ & 2.0540 \\
\hline \multirow{4}{*}{$\begin{array}{l}\text { Socioeconomic } \\
\text { condition }\end{array}$} & $\leq 10,000$ (Ref) & & & \\
\hline & $>10,000-20,000$ & 1.042 & $0.7731-2.3213$ & 1.3396 \\
\hline & $>20,000-50,000$ & 0.0701 & $0.9595-2.8518$ & 1.6542 \\
\hline & $>500,000$ & 0.3866 & $0.7024-2.4905$ & 1.3226 \\
\hline \multirow{2}{*}{ Sun Exposure } & Daily (Ref) & & & \\
\hline & Occasional & 0.0572 & $0.9898-1.9836$ & 1.4012 \\
\hline \multirow{4}{*}{ Seasonal } & Summer (Ref) & & & \\
\hline & Rainy & 0.2171 & $0.4076-1.2262$ & 0.7069 \\
\hline & Spring & 0.8835 & $0.6142-1.5214$ & 0.9667 \\
\hline & Winter & 0.0065 & $1.1969-3.0163$ & 1.90 \\
\hline
\end{tabular}

In Winter season Vit D insufficiency occurs significantly more than summer $(\mathrm{p}=0.003)$. Children in Winter season were also statistically and clinically $(\mathrm{p}=$ $0.006), \mathrm{CI}=1.19-3.01)$ associated with Hypovitaminosis $\mathrm{D}(\mathrm{OR}=1.9)($ Table 1).

Regarding clinical variables only proportion of children with wheeze has significant Hypovitaminosis D ( $\mathrm{p}=0.003$ ) (Table 3). Table 4 revealed that feeding problem, lack of growth and speech problem had lower odds of association with vitamin D insufficiency and all other clinical variables had some association with Vitamin D insufficiency which are not statistically (All p-values are $>0.05$ ) and clinically significant (All CI includes 1). Only wheezy children had both statistically and clinically significant association with Hypovitaminosis D $(\mathrm{OR}=1.83, \mathrm{P}$ $=0.007, \mathrm{CI}=1.17-2.84$ ). 
Table 3. Proportion of clinical variables in Hypovitaminosis $\mathrm{D}^{\dagger}$.

\begin{tabular}{|c|c|c|c|}
\hline Variable & $\begin{array}{c}\text { Proportion in } \\
\text { Hypovitaminosis } \mathrm{D}^{\mathrm{t}}\end{array}$ & $\begin{array}{l}\text { Proportion in sufficiency } \\
\text { of Vitamin } D^{k}\end{array}$ & p-value \\
\hline Cough & $107 / 265(40.37 \%)$ & $100 / 259(38.61 \%)$ & 0.340 \\
\hline Respiratory Distress & $32 / 265(12.07 \%)$ & $31 / 259(11.96 \%)$ & 0.484 \\
\hline Feeding Problem & $23 / 265(08.67 \%)$ & $34 / 259(13.12 \%)$ & 0.050 \\
\hline Fever & $27 / 265(10.18 \%)$ & $22 / 259(08.49 \%)$ & 0.251 \\
\hline Lack of growth & $10 / 265(03.77 \%)$ & $14 / 259(05.40 \%)$ & 0.186 \\
\hline Seizure & $10 / 265(03.77 \%)$ & $7 / 259(02.70 \%)$ & 0.245 \\
\hline Development Failure & $7 / 265(02.64 \%)$ & $4 / 259(01.54 \%)$ & 0.189 \\
\hline Speech Problem & $3 / 265(01.13 \%)$ & $8 / 259(03.08 \%)$ & 0.059 \\
\hline Wheeze & $65 / 265(24.52 \%)$ & $39 / 259(15.05 \%)$ & 0.003 \\
\hline Anaemia & $83 / 265(31.32 \%)$ & $69 / 259(26.64 \%)$ & 0.119 \\
\hline
\end{tabular}

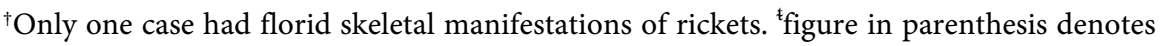
percentage.

Table 4. Multiple logistic analyses of clinical variables associated with Hypovitaminosis D.

\begin{tabular}{cccc}
\hline Variable & P value & Confidence interval & Odds ratio \\
\hline Cough & 0.679 & $0.7585-1.5287$ & 1.07 \\
Respiratory distress & 0.970 & $0.5966-1.7103$ & 1.01 \\
Feeding problem & 0.104 & $0.3595-1.1005$ & 0.62 \\
Fever & 0.505 & $0.6768-2.2068$ & 1.22 \\
Lack of growth & 0.374 & $0.2992-1.5742$ & 0.68 \\
Seizure & 0.491 & $0.5291-3.7671$ & 1.41 \\
Development failure & 0.386 & $0.5002-5.9808$ & 1.72 \\
Speech problem & 0.133 & $0.0942-1.3695$ & 0.35 \\
Wheeze & 0.0070 & $1.1798-2.8488$ & 1.83 \\
Anaemia & 0.238 & $0.8600-1.8336$ & 1.25 \\
\hline
\end{tabular}

\section{Discussion}

Hypovitaminosis D is found in more than half of children in our study. The similar high prevalence was reported in other Bangladeshi and Indian studies [7] [14]. High Prevalence was also reported in Children of China, Mongolia, Middle East, sub-Saharan area and Latin America [22]. Increased prevalence may be due to higher skin pigmentation, increased pollution impairing Vit D synthesis, higher fibre rich diet which contain more phosphate and phytates that deplete Vitamin D and more 25 hydroxyvitamin D-24-hydroxylase that degrades $25(\mathrm{OH})$ Vit $\mathrm{D}$ to inactive metabolites [8] [23].

In this study (Table 1 and Table 2), Hypovitaminosis D was found more in children $>5$ years than those of $1-5$ yrs. However infants suffered more than children of $1-5$ years, probably proportion of infants is much lower than that of 1 - 5 years. In each category at least $42 \%$ suffered from insufficiency of Vitamin D. Hence in our children Hypovitaminosis D is present from birth. Vitamin D insufficiency was also found higher among American children aged 6 - 11 years (73\%) than children aged 1 - 5 years (63\%) [24]. The same type of prevalence 
was also shown in other study in Bangladesh [25]. VitD insufficiency increases with increasing age due to higher mineral demand of their growing bones [26]. Actually in our population Hypovitaminosis D is present from birth which may be due to lower Vitamin intake during pregnancy.

Female children suffered from Hypovitaminosis D more than male (Table 1). Same is reported in a study in America (girls vs Boys: 71\% vs 67\%) [24] (Mansbach, 2009). Though statistically and clinically not significant, still female children a bit at more risk $(\mathrm{OR}=1.16)$ than male (Table 2$)$. Probably it is due to more clothing and less outdoor physical activity in case of female children [27].

Regarding feeding pattern it was shown in Table 2 that the formula fed child is less likely to develop hypovitaminosis $\mathrm{D}$ [OR $=-0.321]$ and children taking home made food are also less risk of developing hypovitaminosis $\mathrm{D}$ [OR = 0.526], in comparison to exclusive breastfed babies (Table 2). It is now established that exclusive breastfeeding without vitamin $\mathrm{D}$ supplements or adequate sunlight exposure are important risk factors for vitamin D deficiency in infants [28].

High weight for age children has significantly increased proportion of Vitamin D insufficiency ( $\mathrm{p}=0.007$ ) (Table 1$)$. Logistic regression had shown (Table 2) that compared with normal weight for age subjects with low weight for age are at decreased risk $(\mathrm{OR}=0.74)$ and subjects with high weight for age are with increased risk of suffering from hypovitaminosis $\mathrm{D}$ [OR = 3.65]. Absoud $\mathrm{M}$, Cummins C, Lim MJ et al., found that there is a association of higher risk of VDI among children who were overweight [29]. It has been suggested that higher body fat causes increased sequestration of Vitamin D [30].

Table 1 showed Hypovitaminosis D is significantly less in rural children than Urban $(p=0.00001)$. Logistic regression shows that rural populations are 0.194 times less likely to suffer from hypovitaminosis $\mathrm{D}$ than urban populations (Table 2). In other studies in India, Pakistan and Ethiopia Hypovitaminosis D is also more prevalent in urban population. It is attributable to dress code, occupation and longer duration of exposure to sunlight (long outdoor physical activity) in rural children [31] [32].

Table 1 showed children going to different grades of school had significantly higher proportion of Hypovitaminosis D than children not going to school at al. Logistic regression had shown that all kindergarten, Primary and High school children had increased risk, it is highest in primary school which is significant both statistically $(\mathrm{p}=0.0005)$ and clinically $(\mathrm{CI}=1.41-3.41)$ (Table 2$)$. The same picture is evident in other studies in Montreal, Afghanistan and other studies [22] [33] [34]. This difference may be r elated to dress code, timing and duration of outdoor sun exposure, in different categories of school education.

Association between sun exposure and vitamin D status Table 1 had shown that in children with occasional sun exposure hypovitaminosis D was significantly found $(\mathrm{p}=0.02)$. Logistic regression in Table 2 had shown occasionally sun exposed group were 1.40 times more likely to develop hypovitaminosis D in comparison to daily sun exposure group. In our study, (Table 1) among 265 
subjects, prevalence of Hypovitaminosis D in Rainy and Spring seasons is not significantly different from Summer but in winter season it is significantly high $(\mathrm{p}=0.03)$ Logistic regression (Table 2$)$ had shown subjects in winter season are at 1.9 times higher risk in comparison to summer season which is both statistically and clinically significant $(\mathrm{p}=0.006$; $\mathrm{CI}=1.196-3.016)$. In many studies vitamin $\mathrm{D}$ status of children was found to be related to timing of sun exposure and amount of skin exposed where increased outdoor exposure was found to be positively correlated with increased vitamin D level [35].

The present study (Table 1 ) has shown that children of high socio-economic group significantly suffered from Hypovitaminosis D $(p=0.03)$. Though logistic regression analysis (Table 2) showed High socio-economic group is at significant risk ( $\mathrm{OR}>1)$, it was not statistically and clinically significant (CI included 1). Linhares et al. has also shown that there is no significant difference of Vitamin D level in two groups [36]. Probably low income group had more time of sun exposure (well off children are more engaged in digital games, less outdoor activity, more risk of obesity and less space for outdoor games in urban children [37].

Among the clinical variables only wheeze has significant $(\mathrm{p}=0.003)$ occurrence in children with Hypovitaminosis D (Table 3). Although feeding problem, lack of growth and speech problem were at less risk of association with vitamin $\mathrm{D}$ insufficiency, the significant association $(\mathrm{OR}>1)$ of other clinical parameters excepting Wheeze ( $\mathrm{p}=0.007, \mathrm{CI}=1.179-2.848)$ are statistically and clinically significant. Lower respiratory tract infection with wheeze was also found in north-eastern rural Bangladesh and Turkey but Rahman et al. did not find any association of wheeze with Hypovitaminosis D [25] [38].

\section{Limitation}

Sampling was purposive. Not whole paediatric population of Bangladesh was included. Most of data were by self-reporting of guardians. Besides, type of supplementation, food habit related data and life styles were not addressed.

\section{Conclusion and Recommendation}

Hypovitaminosis D is highly prevalent in the pediatric population of south-eastern zone of Bangladesh. Age $>5$ years, Urban dwellers, female, breast fed infants, high weight for age, Higher socio-economic strata, occasional sun exposure and winter season, school going children and only clinical parameter wheeze had significant association with Vitamin D Insufficiency. Multi-center RCT throughout Bangladesh will give idea about predictors of Hypovitaminosis D in Bangladesh. As it is prevalent from age 0 , vitamin $\mathrm{D}$ supplementation during antenatal period and awareness of Vitamin $\mathrm{D}$ fortification may be ensured.

\section{Acknowledgements}

We would like to pay our immense gratitude to all patients for allowing us to do 
the study. We are also very much thankful to all the staff of our private clinic.

\section{Conflicts of Interest}

The authors declare no conflicts of interest regarding the publication of this paper.

\section{References}

[1] Heaney, R.P. (2008) Vitamin D in Health and Disease. Clinical Journal of the American Society of Nephrology, 3, 1535-1541.

https://doi.org/10.2215/CJN.01160308

[2] Rathi, N. and Rathi, A. (2011) Vitamin D and Child Health in the 21st Century. Indian Pediatrics, 48, Article No. 619. https://doi.org/10.1007/s13312-011-0107-9

[3] Ashraf, S. and Mughal, M.Z. (2002) The Prevalence of Rickets among Non-Caucasian Children. Archives of Disease in Childhood, 87, 263-264.

https://doi.org/10.1136/adc.87.3.263-a

[4] Strand, M.A., Perry, J., Jin, M., Tracer, D.P., Fischer, P.R., Zhang, P., et al. (2007) Diagnosis of Rickets and Reassessment of Prevalence among Rural Children in Northern China. Pediatrics International, 49, 202-209.

https://doi.org/10.1111/j.1442-200X.2007.02343.x

[5] Norris, J.M. (2001) Can the Sunshine Vitamin Shed Light on Type 1 Diabetes. Lancet, 358, 1476-1478. https://doi.org/10.1016/S0140-6736(01)06570-9

[6] Fuleihan, G.E.-H. and Deeb, M. (1999) Hypovitaminosis D in a Sunny Country. New England Journal of Medicine, 340, 1840-1841. https://doi.org/10.1056/NEJM199906103402316

[7] Zaman, S., Hawlader, M.D.H., Biswas, A, Hasan, M., Jahan, M. and Ahsan, G.U. (2017) High Prevalence of Vitamin D Deficiency among Bangladeshi Children: An Emerging Public Health Problem. Health, 9, 1680-1688. https://doi.org/10.4236/health.2017.912123

[8] Agarwal, K.S., Mughal, M.Z., Upadhyay, P., Berry, J.L., Mawer, E.B. and Puliyel, J.M. (2002) The Impact of Atmosphericpollution on Vitamin D Status of Infants and Toddlers in Delhi, India. Archives of Disease in Childhood, 87, 111-113. https://doi.org/10.1136/adc.87.2.111

[9] Khadilkar, A., Das, G., Sayyad, M., Sanwalka, N., Bhandari, D., Khadilkar, V., et al. (2007) Low Calcium Intake and Hypovitaminosis D in Adolescent Girls. Archives of Disease in Childhood, 92, 1045. https://doi.org/10.1136/adc.2007.116376

[10] Suaini, N.H.A., Koplin, J.J., Ellis, J.A., Peters, R.L., Ponsonby, A.-L., Dharmage, S.C., et al. (2014) Environmental and Genetic Determinants of Vitamin D Insufficiency in 12-Month-Old Infants. The Journal of Steroid Biochemistry and Molecular Biology, 144, 445-454. https://doi.org/10.1016/j.jsbmb.2014.08.018

[11] Webb, A.R (2006) Who, What, Where and When-Influences on Cutaneous Vitamin D Synthesis. Progress in Biophysics and Molecular Biology, 92, 17-25.

https://doi.org/10.1016/j.pbiomolbio.2006.02.004

[12] Holick, M.F. and Chen, T.C (2008) Vitamin D Deficiency: A Worldwide Problem with Health Consequences. American Journal of Clinical Nutrition, 87, 1080S-1086S. https://doi.org/10.1016/S0899-9007(02)00751-7

[13] Vasudevan, J., Reddy, G.M.M., Jenifer, A., Thayumanavan, S., Devi, U. and Rathinasamy, M. (2014) Prevalence and Factors Associated with Vitamin D Deficiency in 
Indian Children: A Hospital Based Cross Sectional Study. Pediatric Oncall Journal, 11, 71-76.

[14] Siddiqui, T.S. and Rai, M.I. (2005) Presentation and Predisposing Factors of Nutritional Rickets in Children of Hazara Division. Journal of Ayub Medical College, 17, 29-32.

[15] Nakamura, K., Nashimoto, M., Okuda, Y., Ota, T. and Yamamoto, M. (2002) Fish as a Major Source of Vitamin Din the Japanese Diet. Nutrition, 18, 415-416. https://doi.org/10.1016/S0899-9007(02)00751-7

[16] El-Hajj, F.G., Nabulsi, M.M., Choucair, M., Salamoun, M., Hajj, S.C., Kizirian, A., et al. (2001) Hypovitaminosis D in Healthy Schoolchildren. Pediatrics, 107, Article No. e53. https://doi.org/10.1542/peds.107.4.e53

[17] McGrath, J.J., Kimlin, M.G., Saha, S., Eyles, D.W. and Parisi, A.V. (2001) Vitamin D Insufficiency in South-East Queensland. Medical Journal of Australia, 174, 150-151. https://doi.org/10.5694/j.1326-5377.2001.tb143195.x

[18] Holick, M.F. (2006) High Prevalence of Vitamin D Inadequacy and Implications for Health. Mayo Clinic Proceedings, 81, 353-373. https://doi.org/10.4065/81.3.353

[19] Hossain, H.T., Islam, Q.T., Khandaker, Md.A.K. and Ahasan, H.N. (2018) Study of Serum Vitamin D Level in Different Socio-Demographic Population-A Pilot Study. Journal of Medicine, 19, 22-29. https://doi.org/10.3329/jom.v19i1.34836

[20] Islam, A.K.M.M., Hasan, M.N., Rahman, K.M., Asaduzzaman, M., Rahim, M.A., Zaman, S., et al. (2019) Vitamin D Status in Bangladeshi Subjects: A Laboratory Based Study. BIRDEM Medical Journal, 9, 202-206. https://doi.org/10.3329/birdem.v9i3.43081

[21] Mahmood, S., Rahman, M., Biswas, S.K., Shaikh Saqueeb, N., Zaman, S., Manirujjaman, M., et al. (2017) Vitamin D and Parathyroid Hormone Status in Female Garment Workers: A Case-Control Study in Bangladesh. BioMed Research International, 2017, Article ID: 4105375. https://doi.org/10.1155/2017/4105375

[22] Arabi, A., El Rassi, R. and El-Hajj, F.G. (2010) Hypovitaminosis D in Developing Countries-Prevalence, Risk Factors and Outcomes. Nature Reviews Endocrinology, 6, 550-561. https://doi.org/10.1038/nrendo.2010.146

[23] Awumey, E.M., Mitra, D.A. and Hollis, B.W. (1998) Vitamin D Metabolism Is Altered in Asian Indians in the Southern United States: A Clinical Research Center Study. Journal of Clinical Endocrinology \& Metabolism, 83, 169-173. https://doi.org/10.1210/jc.83.1.169

[24] Mansbach, J.M., Ginde, A.A. and Camargo, C.A. (2009) Serum 25-Hydroxyvitamin D Levels among US Children Aged 1 to 11 Years: Do Children Need More Vitamin D. Pediatrics, 124, 1404-1410. https://doi.org/10.1542/peds.2008-2041

[25] Roth, D.E., Shah, M.R., Black, R.E. and Baqui, A.H. (2010) Vitamin D Status of Infants in Northeastern Rural Bangladesh: Preliminary Observations and a Review of Potential Determinants. Journal of Health, Population and Nutrition, 28, 458-469. https://doi.org/10.3329/jhpn.v28i5.6154

[26] Ala-Houhala, M., Parviainen, M.T., Pyykko, K. and Visakorpi, J.K. (1984) Serum 25-Hydroxyvitamin D Levels in Finnish Children Aged 2 to 17 Years. Acta Paediatrica, 73, 232-236. https://doi.org/10.1111/j.1651-2227.1984.tb09934.x

[27] Puri, S., Marwaha, R.K., Agarwal, N., Tandon, N., Agarwal, R. and Grewal, K. (2008) Vitamin D Status of Apparently Healthy Schoolgirls from Two Different Socioeconomic Strata in Delhi: Relation to Nutrition and Lifestyle. British Journal of Nutrition, 99, 876-882. https://doi.org/10.1017/S0007114507831758 
[28] Zhang, W., Stoecklin, E. and Eggersdorfer, M. (2013) A Glimpse of Vitamin D Status in Mainland China. Nutrition, 29, 953-957. https://doi.org/10.1016/j.nut.2013.01.010

[29] Absoud, M., Cummins, C., Lim, M.J., Wassmer, E. and Shaw, N. (2011) Prevalence and Predictors of Vitamin D Insufficiency in Children: A Great Britain Population Based Study. PLoS ONE, 6, Article ID: e22179. https://doi.org/10.1371/journal.pone.0022179

[30] Martini, L.A. and Wood, R.J. (2006) Vitamin D Status and the Metabolic Syndrome. Nutrition Reviews, 64, 479-486. https://doi.org/10.1111/j.1753-4887.2006.tb00180.x

[31] Harinarayan, C.V. and Joshi, S.R. (2009) Vitamin D Status in India-Its Implications and Remedial Measures. Journal of the Association of Physicians of India, 57, 40-48.

[32] Herrador, Z., Sordo, L., Gadisa, E., Buño, A., Gómez-Rioja, R., Jose Manuel Iturzaeta, J.M., et al. (2014) Micronutrient Deficiencies and Related Factors in School-Aged Children in Ethiopia: A Cross-Sectional Study in Libo Kemkem and Fogera Districts, Amhara Regional State. PLoS ONE, 9, Article ID: e112858. https://doi.org/10.1371/journal.pone.0112858

[33] Paul, G., Brehm, J.M., Alcorn, J.F., Holguín, F., Aujla, S.J. and Celedón, J.C. (2012) Vitamin D and Asthma. American Journal of Respiratory and Critical Care Medicine, 185, 124-132. https://doi.org/10.1164/rccm.201108-1502CI

[34] Rajakumar, K., Moore, C.G., Yabes, J., Olabopo, F., Haralam, M.A., Comer, D., et al. (2015) Effect of Vitamin D 3 Supplementation in Black and in White Children: A Randomized, Placebo-Controlled Trial. The Journal of Clinical Endocrinology \& Metabolism, 100, 3183-3192. https://doi.org/10.1210/jc.2015-1643

[35] Bose, S., Breysse, P.N., McCormack, M.C., Hansel, N.N., Rusher, R.R., Matsui, M., et al. (2013) Outdoor Exposure and Vitamin D Levels in Urban Children with Asthma. Nutrition Journal, 12, Article No. 81. https://doi.org/10.1186/1475-2891-12-81

[36] Linhares, E.R., Jones, D.A., Round, J.M. and Edwards, R.H.T. (1984) Effect of Nutrition on Vitamin D Status: Studies on Healthy and Poorly Nourished Brazilian Children. American Journal of Clinical Nutrition, 39, 625-630. https://doi.org/10.1093/ajcn/39.4.625

[37] Douglas, A.G., Olivia, N.B., Hyekyung, C., Angeline, K. and David, A.W. (2017) Bedroom Media: One Risk Factor for Development. Developmental Psychology, 53, 2340-2355. https://doi.org/10.1037/dev0000399

[38] Uysalol, M., Uysalol, E.P., Yilmaz, Y., Parlakgul, G., Ozden, T.A., Ertemet, H.V., et al. (2014) Serum Level of Vitamin D and Trace Elements in Children with Recurrent Wheezing: A Cross-Sectional Study. BMC Pediatrics, 14, Article No. 270.

https://doi.org/10.1186/1471-2431-14-270 